\title{
HEAVY METALS ANALYSIS OF MAI-ALLO POND IN GWALE LOCAL GOVERNMENT AREA, KANO STATE, NIGERIA
}

\author{
*Karaye, M. M. and Ibrahim, H. A. \\ Biology Department, Sa'adatu Rimi College of Education, P.M.B. 3218, Kumbotso, Kano, Nigeria \\ *Corresponding authors’ email: karayemaryam@gmail.com
}

\begin{abstract}
Study of Seven heavy metals namely, Zinc, Lead, Copper, Cadmium, Manganese, Chromium and Nickel was conducted in Mai-Allo pond, Gwale, Kano State in order to assess the concentration of the heavy metals in the pond. The results of the heavy metals showed that $\mathrm{Zn}$ has a value of $0.34 \pm 0.17 \mathrm{mg}^{-1}$ in the wet season and $0.49 \pm 0.37 \mathrm{mg}^{-1}$ in the dry season, $\mathrm{Cu}$ has a value of $1.42 \pm 0.14 \mathrm{mg}^{-1}$ in the wet season and $0.64 \pm 0.09 \mathrm{mg}^{-1} \mathrm{in}$ the dry season, and $\mathrm{Ni}$ also has $0.12 \pm 0.02 \mathrm{mg}^{-1}$ in the wet season and $0.23 \pm 0.13 \mathrm{mg}^{-1}$ in the dry season, all these were within acceptable limits, while $\mathrm{Pb}$ with a value of $0.05 \pm 0.02 \mathrm{mg}^{-1}$ was within the limits during the wet season but during the dry season, the value $0.14 \pm 0.09 \mathrm{mg}^{-1}$ exceeds the limits. Cd has a value of $0.06 \pm 0.01$ in the wet season and $0.17 \pm 0.12$ in the dry season, $\mathrm{Cr}$ has $0.36 \pm 0.12$ in the wet season and $0.04 \pm 0.07$ in the dry season, and $\mathrm{Mn}$ also has values of $0.46 \pm 0.12$ and $0.22 \pm 0.03$ in the wet and dry seasons respectively. Hence there was no significant difference $(\mathrm{P}>0.05)$ in the mean values of the sampling stations of the heavy metals during the wet and dry seasons. The study showed that the pond water was polluted with some heavy metals and hence measures must be taken to ensure the safety of the aquatic ecosystem, humans and the environment.
\end{abstract}

Keywords: Limnology, wet season, dry season and water.

\section{INTRODUCTION}

Heavy metals are classified as metallic elements that have relatively high atomic weight and are poisonous at low concentrations. They are natural components of the earth crust and they cannot be degraded or destroyed (Lentech, 2011). They have atomic weight between 63.545 and $200.5 \mathrm{~g}$ (Kennish, 1992). The toxicity of these metals has also been demonstrated throughout history: Greek and Roman physicians diagnosed symptoms of acute lead poisoning long before toxicology became a science. Exposure to heavy metals has been linked with developmental retardation, various cancers, kidney damage and even death (Abdulaziz and Mohammed, 1997).

Living organisms require trace amount of some heavy metals such as cobalt, copper, manganese, vanadium, molybdenum, iron and strontium for metabolic processes, but in excess, these metals can also be detrimental to the organisms (Science Daily, 2012). Heavy metals can enter a water supply through pollution by industrial and consumer wastes or even from acidic rain breaking down soils and releasing heavy metals into streams and ground water (Lentech, 2011). Heavy metals or chemical elements are easily introduced into aquatic system as a result of chemical weathering of soil and rocks from volcanic eruptions and from a variety of human activities involving processing or using of metals or substances that contained metals (Lentech 2006). There are two different types of sources of pollutants in our water bodies, namely: point source and non-point or diffuse source. Point source is a localized pollution where pollutants come from single identifiable sources. The second type of pollution sources are non-point or diffuse sources, where pollutants come from dispersed sources and often difficult to identify sources (Lentech, 2006). The major threats to human wellbeing are associated with heavy metals such as lead, arsenic, cadmium and mercury (Butu and Iguisi, 2013).

A legacy of incident tells us about the seriousness of high levels of exposure to some metals, especially cadmium and methyl mercury (Nriagu, 1992). In the 1950s, chronic poisoning from rice coupled with dietary deficiencies caused epidemic of kidney damage and a painful skeletal disease among middle aged women in Japan; the itaitai disease. Also in Japan, mercury poisoning from fish in a polluted bay became known as Minimata disease, (Nriagu, 1992).

Industrial pollution seriously threatens the quality of water resources and the environment in Kano. For instance, the deposition of refuse from food industries has been reported to have contaminated water from virtually all the boreholes in Bompai industrial estate (Egboka et al., 1989). The incidence of water discharge is possibly the biggest threat to city farming and has been identified as a major environmental hazard in the region (Tanko, 2002).

Bordoloi et al. (2002) had reported that metals deposited in the sediments come out during heavy rainfall and flow into the 
water. Roberto et al. (2008) had also reported that rainfall infiltrate the soil and underlying geologic formations, dissolve metals causing them to seep into aquifers and finally water system thus increasing their concentrations. $\mathrm{Cu}$ and $\mathrm{Zn}$ form substantial part of the wastes and effluents from workshops, industries and markets around the lake and may have been carried to the lake, river, pond etc. during the rains thus resulting in their higher concentration during the rainy season.

Manganese, although is not a toxic metal, it imparts objectionable and tenacious stains to laundry plumbing fixtures. It is found to occur in the domestic waste water. (Councell et al., 2004).

The high trace metal concentration of manganese may originate from anthropogenic sources such as waste incineration, vehicle operation, combustible consumption, and fertilizers use which likely come from the upper basin of the lotic systems that flow into the wetland (Councell et al., 2004). Nickel is easily accumulated in the biota, particularly in the phytoplankton or other aquatic plants, which are sensitive bioindicators of water pollution. It can be deposited in the sediment by such processes as precipitation, complexation and adsorption on clay particles and via uptake by biota (Barałk et al 1999). Nickel and nickel compounds have many industrial and commercial uses and the progress of industrialization has led to increased emission into ecosystems.

Though zinc is involved in nucleic acid synthesis and participates in a variety of metabolic processes involving carbohydrates, lipids, proteins and nucleic acid (Mc. Dowell, 1992), it can be toxic also when present in excess amount as changes in blood parameters and tissue structures have been reported on exposure to zinc (Gupta and Chakraborty, 1995; Banerjee, 1998).

\section{MATERIALS AND METHOD}

\section{Sample collection site}

The Sample collection site was Mai Allo pond in Gwale Local Government (Figure 1), which was one of the many ponds built by Kano people in ancient times during wars and raids. The ponds were dug around Kano Walls from outside and inside to prevent enemies from attacking the city (Daily trust, 2020).

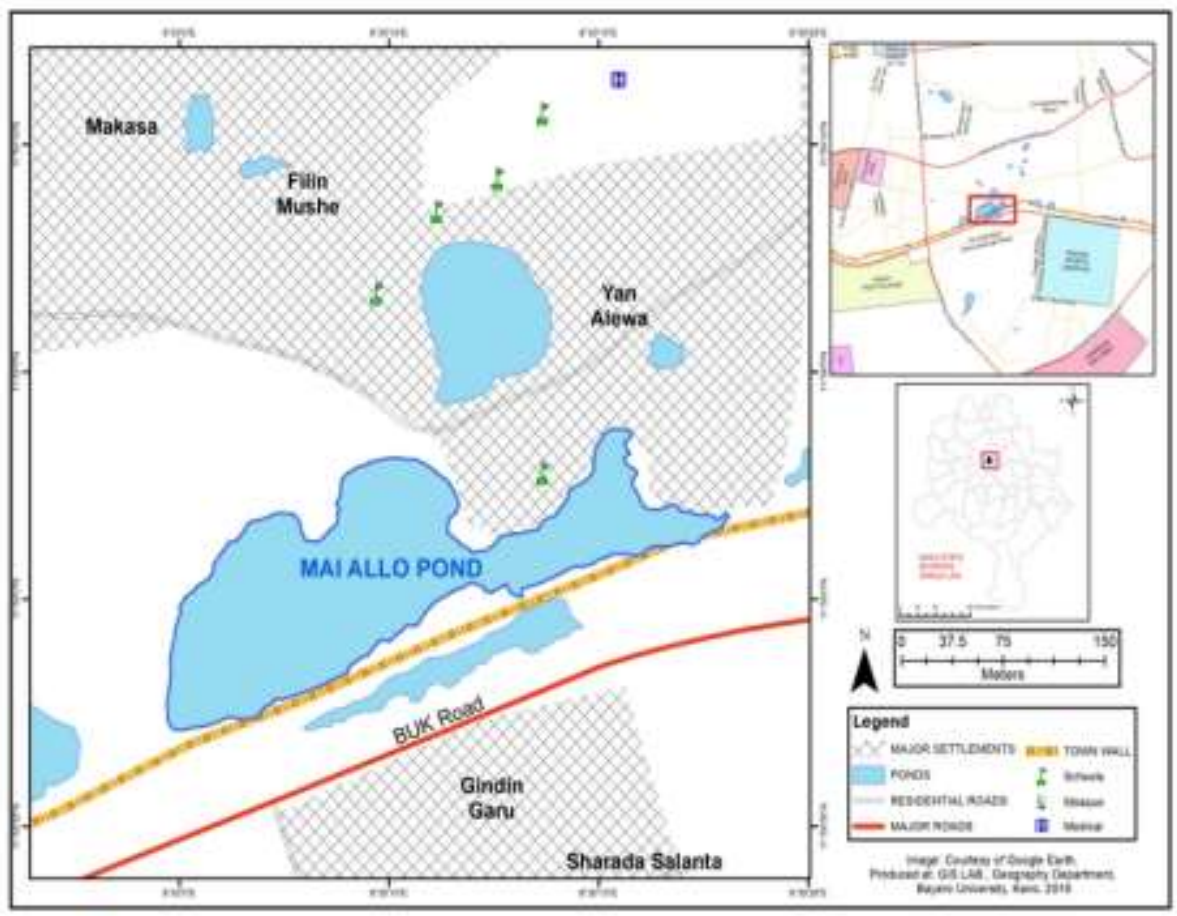

Figure 1: Map Showing Mai Allo Pond Gwale Local Government Kano State 


\section{Sample Collection}

Samples were collected from Mai Allo Pond at early hours of the day in the month of January which is during the dry season and August which is during the wet season to determine the level of Heavy metals present in the pond.

\section{Digestion of the water sample}

To the sample, $5 \mathrm{~mL}$ of $65 \% \mathrm{HNO} 3$ was added, and then the mixture was boiled gently over a water bath $\left(90^{\circ} \mathrm{C}\right)$ for $1-2 \mathrm{~h}$ or until a clear solution was obtained. Later, $2.5 \mathrm{~mL}$ of $65 \%$ HNO3 was added, followed by further heating until total digestion (Zheljazkov and Nielson 1996).

\section{Heavy Metal Analysis}

The concentrations of $\mathrm{Cd}, \mathrm{Cr}, \mathrm{Cu}, \mathrm{Mn}, \mathrm{Ni}, \mathrm{Pb}$ and $\mathrm{Zn}$ in the final solutions were determined by an atomic absorption spectrometer (AAS) (Hitachi Z-8100, Japan).

\section{Data analysis}

All data generated were collated, checked and analyzed using instat Guide statistical package. Quantitative variables were described using mean and standard deviation. Qualitative variables were presented as bar chart and line graph. Analysis of variance (ANOVA) was used to determine the differences between means. $\mathrm{P}$ value of $<0.05$ was regarded as significant and $P$ value $>0.05$ was regarded as insignificant.

\section{RESULTS}

The result of the mean values of heavy metals analyzed in the water samples are presented in Table 1 . Zinc has a higher value during the dry season and also the value obtained during both the wet and dry season were higher than the World health Organization (WHO) maximum acceptable concentration (MAC) but lower than the Maximum Permissible Level (MPL) of WHO. Lead also has a higher value during the dry season and this value exceeds both the MAC and MPL values. But for copper the value of metal concentration was higher during the wet season. The values for both the wet and dry season of copper were lower than both the MAC and MPL values which was the same for manganese. The value of Cadmium during the dry season is higher than the value

obtained during the wet season and both were higher than the MAC and MPL values. Chromium has a higher value during the wet season and this value is higher than MAC value, whereas the value during the dry season is lower than the MAC value. The value of Nickel obtained during the dry season is lower than the value obtained during the wet season. Nickel has no guideline of WHO.

Table 1: Mean values of seasonal variation of heavy metals

\begin{tabular}{|c|c|c|c|c|}
\hline Metals & Wet season $(\mathrm{mg} / \mathrm{l})$ & Dry season(mg/l) & $\begin{array}{c}\text { WHO } \\
\mathrm{MAC}\left(\mathrm{mg} / \mathrm{dm}^{3}\right)\end{array}$ & $\begin{array}{l}\text { WHO } \\
\text { MPL }\left(\mathrm{mg} / \mathrm{dm}^{3}\right)\end{array}$ \\
\hline Zinc & $0.34 \pm 0.17$ & $0.49 \pm 0.37$ & 0.05 & 15.0 \\
\hline Lead & $0.05 \pm 0.02$ & $0.14 \pm 0.09$ & 0.05 & 0.10 \\
\hline Copper & $1.42 \pm 0.14$ & $0.64 \pm 0.09$ & 0.05 & 15.0 \\
\hline Cadmium & $0.06 \pm 0.01$ & $0.17 \pm 0.12$ & 0.005 & 0.01 \\
\hline Manganese & $0.46 \pm 0.12$ & $0.22 \pm 0.03$ & 0.1 & 0.5 \\
\hline Chromium & $0.36 \pm 0.12$ & $0.04 \pm 0.07$ & 0.05 & NG \\
\hline Nickel & $0.12 \pm 0.02$ & $0.23 \pm 0.13$ & NG & NG \\
\hline
\end{tabular}

Source: Olajire and Imeokpara (2000).

Key:

WHO = World Health Organization

MAC $=$ Maximum Admissible Concentration,

MPL = Maximum Permissible Level

$\mathrm{NG}=\quad$ No Guideline 


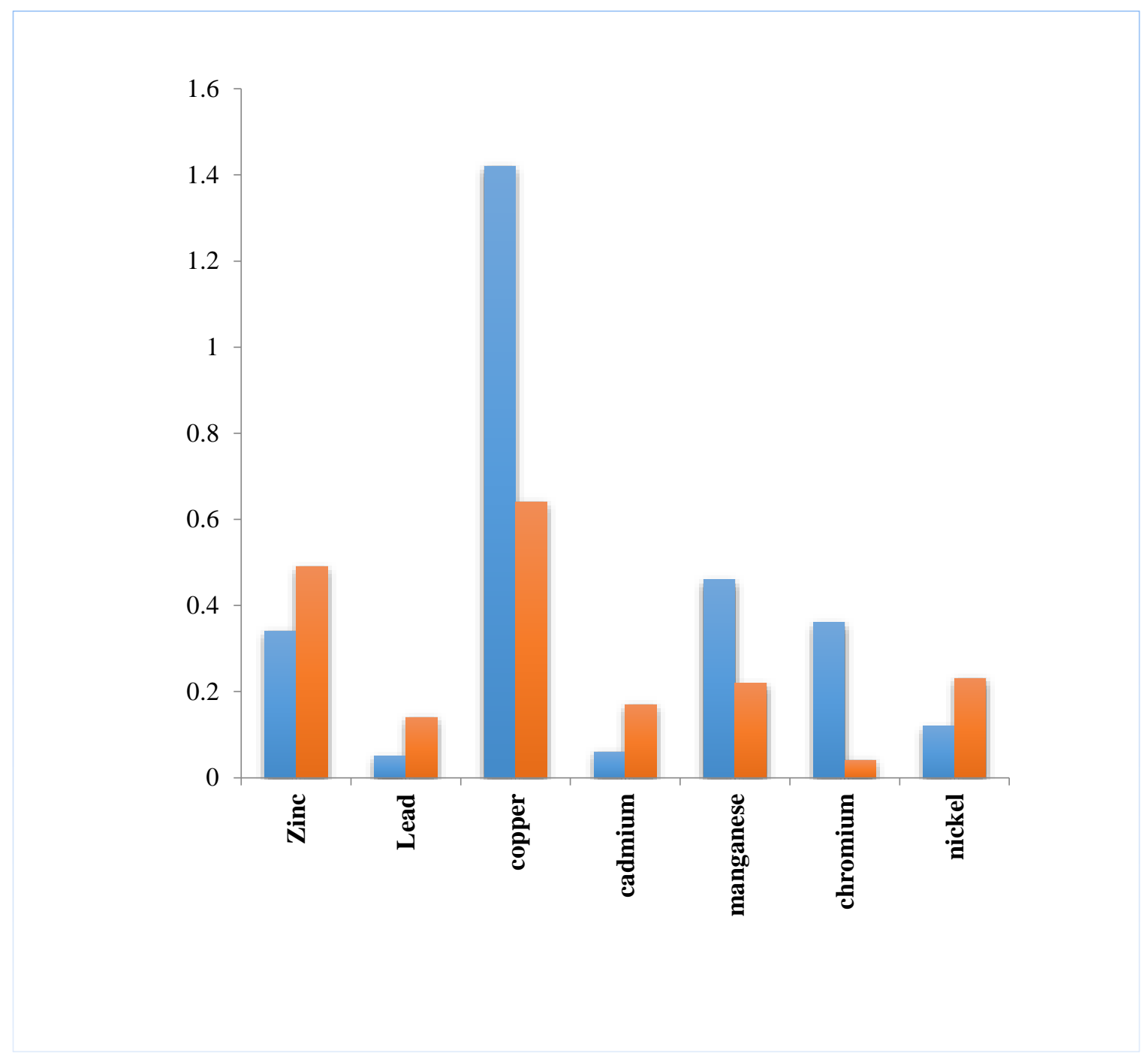

Fig 1. Graph showing seasonal variations of Heavy metals in Mai allo pond

\section{DISCUSSION}

The amount of lead $(\mathrm{Pb})$ found during the wet season was within the maximum admissible and permissible limit of WHO while during the dry season the amount of $\mathrm{Pb}$ exceeds the limits. The high level of $\mathrm{Pb}$ in the pond water during the dry season could be attributed to the amount of raw sewage from nearby homes and dust which holds a huge amount of $\mathrm{Pb}$ from the combustion of petrol in automobile cars (Hardman et al. 1994). This also agreed with Banat et al., (1998) that higher levels of $\mathrm{Pb}$ often occur in water bodies near highways and large cities due to high gasoline combustion as the pond is near a major road.

Beliles (1979) mentioned that the major sources for manganese in air and water are iron and steel manufacturing and the burning of diesel fuel in motor cars. Therefore, the moving cars on the road could be a reason for high level of $\mathrm{Mn}$ in the pond water. 
The value of Mn obtained in all the seasons were higher than the maximum acceptable concentration $(0.1 \mathrm{mg} / \mathrm{l})$ but lower than the maximum allowable concentration $(0.5 \mathrm{mg} / \mathrm{l})$ recommended by WHO. The value obtained in this study $0.22 \pm 0.03$ during the dry season was in agreement with the value obtained by Javed and Usmani (2013) with a value of $0.21 \mathrm{mg} / \mathrm{l}$.

Zinc ( $\mathrm{Zn})$ concentration in all the seasons was clearly below the maximum admissible concentration of $5.0 \mathrm{mg} / \mathrm{dm}^{3}$ and permissible level of $15.0 \mathrm{mg} / \mathrm{dm}^{3}$ recommended by WHO, the mean value of $0.34 \pm 0.17$ for the wet season and $0.49 \pm 0.37$ for the dry season were below these limits. Abubakar et al. (2015) also recorded $\mathrm{Zn}$ concentration having the mean value of 0.95 which was also below WHO recommended values.

The values for Copper $(\mathrm{Cu})$ in all the seasons were below the maximum permissible level of $15.0 \mathrm{mg} / \mathrm{dm}^{3}$ and above the maximum admissible concentration of $0.05 \mathrm{mg} / \mathrm{dm}^{3}$ recommended by WHO. The value of $\mathrm{Cu}$ during the dry season $(0.64 \pm 0.09)$ was lower than the value obtained in the wet season (1.42 \pm 0.14$)$. The value obtained during the wet season was within the range obtained by Abubakar et al. (2015) which was $(1.19 \mathrm{mg} / \mathrm{l})$. The value obtained during the wet season was higher than the value obtained during the dry season this could be due to the fact that large quantity has been washed from the land into the pond by the rain water.

It can be observed that the value of chromium $(\mathrm{Cr})$ obtained during the dry season was below the maximum admissible concentration of $0.05 \mathrm{mg} / \mathrm{dm}^{3}$ recommended by WHO, while the value obtained during the wet season was also above the maximum admissible concentration of $0.05 \mathrm{mg} / \mathrm{dm}^{3}$ recommended by WHO. The higher value obtained during the rainy season could be linked to the run off of water from various sources into the pond. The values obtained were within the range obtained by Nwachukwu et al. (2014) with value of 0.01-0.65 $\mathrm{mg} / \mathrm{l}$.

Nickel (Ni) showed a lower value in the wet season than in the dry season, this might be due to higher level of water in the pond during the rainy season. The value obtained during the dry season was in agreement with $(0.21 \pm 0.12)$ obtained by Bhat $e t$ al. (2012).

The value of Cadmium obtained in the study in both seasons was well above the maximum admissible concentration and permissible limit of $0.005 \mathrm{mg} / \mathrm{dm}^{3}$ and $0.01 \mathrm{mg} / \mathrm{dm}^{3}$ recommended by WHO. In the rainy season the value obtained was $0.06 \pm 0.01 \mathrm{mg} / \mathrm{l}$ and in the dry season the value obtained was $0.17 \pm 0.12$. These values were within the range of $(0.10 \pm$ $0.07 \mathrm{mg}-1)$ obtained by Bhat et al. (2012).

\section{CONCLUSION AND RECOMMENDATION}

No concentration of metal elements or any metal has been reported as being safe, because long term exposure to low concentration is equally harmful. It can be concluded that the pond water is slightly polluted with zinc, lead, copper, cadmium and manganese during the dry season and zinc copper, cadmium
, manganese and chromium during the wet season as they exceeds the Maximum Acceptable Concentration while lead and cadmium during the dry season and only cadmium in the wet season exceeds the Maximum Permissible Limit of World Health Organization. There is a need to analyze the fish pond water at regular intervals. This is a quality assurance process to ensure that there are no toxic substances in the ponds leading to possible bio-accumulation and magnification. In this way the good health of the aquatic ecosystem, humans and environment can be guaranteed.

\section{REFERENCES}

Abdulaziz, B.A. and Muhammad, H. (1997). Role of Epidemiological Studies in Determining Environmental Impact on Health in Saudi Arabia. Book of Abstract for the Development and Environmental Impact Conference, Riyadh, Saudi Arabia. P. 196

Abubakar, A. J., Yusuf, S. and Shehu, K. (2015). Heavy metal pollution on surface water sources in Kaduna metropolis, Nigerian Science World Journal, 70(2):1-5.

Amadi, A,N., Okoye, N,O., Alabi A,D., Tukur, A. and Angwa, E.M. (2014). Quality Assessment of Soil and Groundwater near Kaduna Refinery and Petrochemical, Northwest Nigeria. Journal of Scientific Research \& Reports, 3(6): 885-893.

Banat, I. M, E. S., Hassan, M. S., El-Shahawi and A. H. AbuHilal. (1998). Post-gulf-war assessment of nutrients, heavy metal ions, hydrocarbons, and bacterial pollution levels in the United Arab Emirates coastal waters. Environ. Inter., 24 (2): 109-116.

Banerjee, V. (1998): Influence of zinc and mercury on blood parameters of the fish Heteropneustes fossilis. Environ. Ecol., 16: 79-84.

Barałk, I.D. and Siepak, J. (1999). Chromium, nickel and cobalt in environmental samples and existing legal norms. Polish J. Environ. Studies, 8: 201.

Beliles, A. A. (1979). The lesser metals. In "Toxicity of Heavy Metals in the Environment". (Ed.F.W.Oehme) Part II. Marcel Dekker Inc.: New York, pp. 565-597.

Bhat, M. M., Narain, K., Andrabi, S.Z.A., Shukla, R.N, Yunus, M. (2012). Assessment of Assessment of Heavy Metal Pollution in Urban Pond Ecosystems. Universal Journal of Environmental Research \& Technology 2 (4)

Bordoloi, R.K., Kotoky, P., Baruah, J., Haque, L. and Borah, G.C. (2002): Heavy metals in thesediments of Tokial River, Assam. IJEP, 22:779-784. 
Butu A.W and Iguisi E.O (2013). Concentration of heavy metals in sediment of river Kubanni, Zaria, Nigeria. Comprehensive Journal of Environment and Earth Sciences Vol. 2(1), pp. 10 17, Feb. 2013

Councell, T.B., Duckenfield, K.U., Landa, E.R.and Callender, E. (2004): Tire-wear particles as a source of zinc to the environment. Env. Sci Tech., 38: 4206-4214.

Egboka, B.C.E, Nwankor, G.I., Orajaka, I.P. and Ejiofor, A.O.(1989). Principles and problems of environmental pollution of groundwater resources with case example from developing countries. Environmental Health Perspective, Nigeria. Pp 7279.

Gregg, L.W. (1989). Water analysis Handbook. H.A.C.H Company, USA. pp. 33-39

Gupta, A.K. and Chakraborty, P. (1995). Effect of zinc on the testes of Notopterus notopterus and its subsequent recovery by EDTA. J. Inland Fish. Soc. India, 27: 57-59.

Hardman, D. J., S. Mceldowney and S. Watte. (1994). Pollution, ecology and biotreatment. Longman Scientific, Technical, England, pp. 322

http://www.dailytrust.com.ng/kano-now troubled-by-its-manyponds.html

Javed M, and Usmani N: Haematological indices of Channa punctatus as an indicator of heavy metal pollution in waste water aquaculture pond, Panethi, India. African J Biotech 2013, 12: $520-525$.

Kennish, L. (1992): Toxicity of heavy metals: effects of Cr and Se on humans health. Journal of Indian Public Health Education, India. 2:36-64.

Lentech (2006). The way fresh water Ecosystem deal with excess metals. Lentech Water Treatment and Air Purification Holding B.V. (1998-2006). www.Lentech.com/heavy-metal.htm

Lentech (2011). Heavy metals. Lentech water treatment and Air purification Holding B.V (1998-2011) www.Lentech/heavymetal.htm.
Mc. Dowell, L.R. (1992). Minerals in animal and human nutrition, A. P. Inc. London, N. Y. 265-275.

Moore, J.W. and Ramamoorthy, S. (1984). Heavy Metals in Natural Waters. AppliedMonitoring andImpact Assessment, 28: 246.

Nriagu, O.J. (1992): Toxic metal pollution in Africa. The Science of the total environment. Elsevier Science Publishers, Amsterdam. 121:1 - 37.

Nwachukwu, R.E., Janefrances, N.I., Ikayi, S.E and Agbazne, V. E. (2014). Health risk assessment in relation to heavy metals in water sources in rural regions of South East Nigeria, International Journal of Physical Sciences, 9(6):109-116.

Olajire, A.A. and Imeokparia, F.E. (2000). A Survey of the water quality of the Osun river; metal monitoring and geochemistry. Bulletin of the Chemical Society of Ethiopia, 14(1):91-108. SHR

Roberto, G.L., Hector, R.A., Ray, O., Juan, A.O and Menda, G. (2008). Heavy metals in Water of the San Pedro River in Chihuahua, Mexico and its potential health risk. Internat. J. of Environ. Res., 5: 91-98.

Setia, K., Kawatra, B.L., Hira, C.K., Mann, S.K.,Bennink, M., Dhaliwal, G.S., Arora, R., Randhawa, N.S. and Dhawan, A.K. (1998): Consumption of heavy metals by adult women in sewage and tubewell irrigated areas. Ecological agriculture and sustainable development, 2: 677-683.

Science Daily (2012). Heavy metals. $\underline{w w w . s c i e n c e d a i l y . c o m}$

Tanko, A.I. (2002). Spatio-temporal patterns of environmental pollution and control in metropolitan Kano. Paper presented at the $4^{\text {th }}$ Annual Nigerian Geographical Association Conference, University of Ilorin, June 03, 2002.

Zheljazkov, V.D.,Nielson, N.E., 1996. Effect of heavy metals on peppermint and cornmint. Plant soil 178, 59-66.

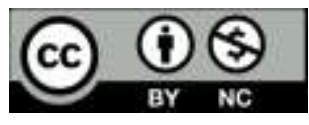

(C)2020 This is an Open Access article distributed under the terms of the Creative Commons Attribution 4.0 International license viewed via https://creativecommons.org/licenses/by/4.0/ which permits unrestricted use, distribution, and reproduction in any medium, provided the original work is cited appropriately. 